\title{
Differential gene expression profiles of gastric cancer cells established from primary tumour and malignant ascites
}

\section{Sakakura*,1,2, A Hagiwara', M Nakanishi',2, K Shimomura',2, T Takagi', R Yasuoka' ${ }^{1,2}$, Y Fujita ${ }^{1,2}$, T Abe', Y Ichikawa ${ }^{3}$, S Takahashi ${ }^{3}$, T Ishikawa ${ }^{3}$, I Nishizuka ${ }^{3}$, T Morita ${ }^{3}$, H Shimada ${ }^{3}$, Y Okazaki ${ }^{4}$, Y Hayashizaki ${ }^{4}$ and H Yamagishi'}

'Department of Digestive Surgery, Kyoto Prefectural University of Medicine, Kamigyo-ku, Kawaramachi-dori, Kyoto 602-8566, Japan; ${ }^{2}$ Department of Hygiene, Kyoto Prefectural University of Medicine, Kamigyo-ku, Kawaramachi-dori, Kyoto 602-8566, Japan; ${ }^{3}$ Department of Surgery-2, Yokohama City University, School of Medicine, 3-9 Fukuura Kanazawa-ku, 236-0004, Yokohama, Japan; ${ }^{4}$ Genomic Sciences Center, RIKEN, Yokohama Institute, I-7-22 Suehiro-cho, Tsurumi-district, Yokohama, 230-0045, Japan

Advanced gastric cancer is often accompanied by metastasis to the peritoneum, resulting in a high mortality rate. Mechanisms involved in gastric cancer metastasis have not been fully clarified because metastasis involves multiple steps and requires a combination of altered expressions of many different genes. Thus, independent analysis of any single gene would be insufficient to understand all of the aspects of gastric cancer peritoneal dissemination. In this study, we performed a global analysis of the differential gene expression of a gastric cancer cell line established from a primary main tumour (SNU-I) and of other cell lines established from the metastasis to the peritoneal cavity (SNU-5, SNU-16, SNU-620, KATO-III and GT3TKB). The application of a high-density cDNA microarray method made it possible to analyse the expression of approximately 2I 168 genes. Our examinations of SNU-5, SNU-16, SNU-620, KATO-III and GT3TKB showed that 24 genes were upregulated and 17 genes down-regulated besides expression sequence tags. The analysis revealed the following altered expression such as: (a) up-regulation of CD44 (cell adhesion), keratins 7, 8, and I4 (epitherial marker), aldehyde dehydrogenase (drug metabolism), CD9 and IP3 receptor type3 (signal transduction); (b) down-regulation of IL2 receptor $\gamma$, IL4-Stat (immune response), p27 (cell cycle) and integrin $\beta 4$ (adhesion) in gastric cancer cells from malignant ascites. We then analysed eight gastric cancer cell lines with Northern blot and observed preferential up-regulation and down-regulation of these selected genes in cells prone to peritoneal dissemination. Reverse transcriptase-polymerase chain reaction confirmed that several genes selected by DNA microarray were also overexpressed in clinical samples of malignant ascites. It is therefore considered that these genes may be related to the peritoneal dissemination of gastric cancers. The results of this global gene expression analysis of gastric cancer cells with peritoneal dissemination, promise to provide a new insight into the study of human gastric cancer peritoneal dissemination.

British Journal of Cancer (2002) 87, I 153 - | I6I. doi:10.1038/sj.bjc.6600580 www.bjcancer.com

(c) 2002 Cancer Research UK

Keywords: peritoneal dissemination; gastric cancer; cDNA microarray

Gastric cancer is the most frequent malignancy of the gastrointestinal tract among Japanese and certain South-East Asian populations and the second most common cause of cancerrelated death in the world (Parkin et al, 1999). The prognosis of gastric cancer has been improving owing to progress in diagnostic techniques and treatment methods for gastric cancer, but peritoneal dissemination is the main cause of recurrence after curative resection of advanced cancer. The prognosis of gastric cancer which has invaded as far as the gastric serosa is still poor with a 5-year survival of less than 35\% (Yamazaki et al, 1989; Shimada and Ajani, 1999). Among these malignant characteristics of gastric cancer cells, metastasis to the peritoneum is an especially complex phenomenon, which requires the involvement of many different genes in multiple steps for tumour cells. Although

* Correspondence: C Sakakura, Department of Digestive Surgery, Kyoto Prefectural University of Medicine, Kamigyo-ku, Kawaramachi-dori, Kyoto 602, Japan; E-mail: sakakura@koto.kpu-m.ac.jp

Revised 9 June 2002; accepted 14 August 2002 many aspects of gastric cancer metastasis await further clarification, adhesion molecules, apoptosis-related genes, and others have been reported to play an important role in peritoneal dissemination of gastric cancers (Tahara et al, 1996; Yawata et al, 1998; Tahara, 2000). It is well known that changes in the expression of these genes enhance cell escape from the primary tumour and resistance to apoptosis, but details of the mechanism involved remain unclear.

Most gastric cancer cell lines have been established from liver metastases, lymph node metastases, or malignant ascites, while few have been established from primary lesions. To investigate the mechanism of gastric cancer peritoneal dissemination, Park et al $(1990,1994)$ established several gastric cancer cell lines, SNU1, SNU-5, SNU-16, and SNU-620 cells, SNU-1 from primary tumour, and others from malignant ascites, which have a high potential for peritoneal dissemination. SNU cell lines have been studied both extensively and intensively. cMET is amplified in SNU-16, overexpression of TGF- $\beta$ type II receptor, CEA, CA19-9, and c-erbB 2 has been confirmed in SNU-1, SNU-5 and SNU16, KATO-III cells have K-sam amplification (Katoh et al, 1992), 
and GT3TKB reduced expression of E-cadherin (Tamura et al, 1996). But their common changes of gene expression have not yet been clarified.

Coordination of multiple genes is involved in metastasis, whereas only one gene or a few genes have been the subject of most previous reports on metastasis. Moreover, differences in metastatic potential are expected to be due to a combination of differently expressed genes. In this context, gene expression analysis of gastric cancer cells with different metastatic potentials in terms of grade and target is extremely relevant for the clarification of the mechanism of gastric cancer peritoneal dissemination. For this study, we performed globally analysed expression profiles of approximately 21000 genes in SNU-1, SNU-5, SNU-16, SNU620, KATO-III, and GT3TKB cells by using a cDNA microarray. By combining this analysis with subsequent confirmation of altered expressions of selected genes by Northern blot analysis or RTPCR, differently expressed genes among these cells could be positively identified. Although further functional analysis is necessary, our results can be expected to prove new insights into the mechanism of gastric cancer metastasis.

\section{MATERIALS AND METHODS}

\section{Cell culture and RNA preparation}

Gastric cancer cell lines SNU-1, SNU-5, SNU-16, SNU-620 cells were established previously by Park et al (1990, 1994, 1997). KATO-III, GT3TKB and MKN 7 were purchased from Riken Cell Bank (Tsukuba, Japan) (Hojo, 1977; Sekiguchi et al, 1978; Tamura et al, 1996). NUGC-3 cells were purchased from Health Science Research Resources Bank (Osaka, Japan). GT3TKB were maintained at $37^{\circ} \mathrm{C}$ in a humidified atmosphere of $5 \% \mathrm{CO}_{2}$ in highglucose DMEM (Sigma, St. Louis, MO, USA), whereas MKN7 and NUGC-3 were maintained in RPMI 1640 (Sigma). Both media were supplemented with $10 \%$ foetal bovine serum, penicillin, and streptomycin. When they reached $80-90 \%$ confluence, cells were washed with ice-cold PBS and homogenised immediately. mRNA extracted from each cell line was extracted by FAST track kit Ver.2 (Invitrogen) according to the manufacturer's instructions. Characteristics of these gastric cancer cell lines (origin, histology, potency of intraperitoneal transplantation) are shown in Table 1.

\section{Experimental model in nude mouse}

Four-week-old female BALB/c nu/nu mice (Clea Japan, Inc., Osaka, Japan) were inoculated intraperitoneally with $5 \times 10^{6}$ gastric cancer cells in $0.5 \mathrm{ml}$ PBS. Four weeks later, the presence of disseminated foci or ascites was determined. All animal experiments were conducted in accordance with institutional guidelines for animal welfare.

Table I Characteristics of gastic cancer cell lines

\begin{tabular}{llll}
\hline Cell line & Origin & Histology & $\begin{array}{l}\text { Transplantation } \\
\text { in peritoneal cavity }\end{array}$ \\
\hline SNU-I & Primary tumor & Poorly diff. adenoca. & Impossible \\
SNU-5 & Malignant ascites & Poorly diff. adenoca. & Possible \\
SNU-16 & Malignant ascites & Poorly diff. adenoca. & Possible \\
SNU-620 & Malignant ascites & Poorly diff. adenoca. & Possible \\
KATO-III & Pleural effusion & Signet ring cell carcinoma & Possible \\
GT3TKB & Malignant ascites & Moderately diff. adenoca. & Possible \\
MKN7 & Lymhode metastses & Well diff. adenoca & Impossible \\
NUGC3 & Lymhnode metastses & Poorly diff. adenoca. & Impossible
\end{tabular}

The characteristics comprise origin, histology and potency of intraperitoneal transplantation.

\section{Preparation of probe}

One microgram of mRNA extracted from each gastric cancer cell line was labelled by incorporating $\mathrm{Cy} 3$ during random-primed reverse transcription. cDNA derived from the reference pool, which we labelled with $\mathrm{Cy} 5$, was used as the expression reference. We combined mRNA from the following cells in equal quantities to make the reference pool: HL60 (acute myeloid leukaemia) and K562 (chronic myeloid leukaemia); NCI-H226 (non-small cell lung); COLO205 (colon); SNB-19 (central nervous system); LOXIMVI (melanoma); OVCAR-3, OVCAR-4 (ovary); CAKI-1 (kidney); PC-3 (prostate); and MCF7 and HS 578T (breast). Twelve highly diverse cell lines were selected on the basis of the results of previous studies (Ross et al, 2000; Scherf et al, 2000). Cell lines were selected from various organs to ensure that the reference RNA contained as many different kinds of gene transcripts as possible.

The labelling was carried out at $42^{\circ} \mathrm{C}$ for $1 \mathrm{~h}$ in a total volume of $30 \mu \mathrm{l}$ containing 400 units of SuperScript II (GIBCO/BRL); $0.1 \mathrm{~mm}$ Cy3-dUTP (or Cy5-dUTP); $0.5 \mathrm{~mm}$ each dATP, dCTP, and dGTP; $0.2 \mathrm{mM}$ dTTP, $10 \mathrm{mM}$ DTT, $6 \mu \mathrm{l}$ of $5 \times$ first-strand buffer, and $6 \mu \mathrm{g}$ of random primers. To remove unincorporated nucleotide, labelled cDNA was mixed with $500 \mu \mathrm{l}$ of binding buffer ( $5 \mathrm{M}$ guanidine thiocyanate per $10 \mathrm{~mm}$ Tris. $\mathrm{HCl}, \mathrm{pH} 7.0$ per $0.1 \mathrm{~mm}$ EDTA containing $0.03 \%$ gelatin and $2 \mathrm{ng} \mu \mathrm{l}^{-1}$ tRNA) and $50 \mu \mathrm{l}$ of silica matrix buffer $(10 \%$ matrix/3.5 M guanidine hydrochloride/20\% glycerol/0.1 mM EDTA/200 mM NaOAc, $\mathrm{pH} 4.8$-5.0), transferred to a GFX column (Amersham Pharmacia), and centrifuged at 15000 r.p.m. in a Sorvall centrifuge (RC3B plus; H6000A/HBB6 rotor) for $30 \mathrm{~s}$. The flow-through was discarded, and the column was washed with $500 \mu \mathrm{l}$ of wash buffer. The adsorbed probe was eluted into a final volume of $17 \mu \mathrm{l}$ of distilled water. This labelled probe was mixed with blocking solution containing $3 \mu \mathrm{l}$ of $10 \mu \mathrm{g} \mu \mathrm{l}^{-1}$ oligo(dA), $3 \mu \mathrm{l}$ of $20 \mu \mathrm{g} \mu \mathrm{l}^{-1}$ yeast tRNA, $1 \mu \mathrm{l}$ of $20 \mu \mathrm{g} \mu \mathrm{l}^{-1}$ mouse Cot1 DNA, $5.1 \mu \mathrm{l}$ of $20 \times$ SSC, and $0.9 \mu \mathrm{l} 10 \%$ SDS (Miki et al, 2001).

\section{Array hybridisation and data analysis}

The RIKEN human cDNA that comprised the target was hybridised in a final volume of $30 \mu \mathrm{l}$; the entire array consists of three multiblocks, and each multiblock required $10 \mu \mathrm{l}$ of hybridisation solution. Before hybridisation, probe aliquots were heated at $95^{\circ} \mathrm{C}$ for $1 \mathrm{~min}$ and cooled at room temperature. Coverslips were hybridised overnight at $65^{\circ} \mathrm{C}$ in a Hybricasette (obtained from ArrayIt.com). After hybridisation, slides were washed in $2 \times \mathrm{SSC} /$ $0.1 \%$ SDS until the coverslips dropped off, and the slides were then transferred into $1 \times \mathrm{SSC}$, shaken gently for $2 \mathrm{~min}$, and rinsed with $0.1 \times$ SSC for $2 \mathrm{~min}$. After washing, slides were spun at 800 r.p.m. in a Sorvall centrifuge (RC-3B plus; H6000A/HBB6 rotor). These slides were scanned on a ScanArray 5000 confocal laser scanner, and the images were analysed by using IMAGENE (BioDiscovery; Los Angeles, CA, USA).

\section{Analysis of the data}

To improve the accuracy of the data, we did the experiment twice, labelling the same RNA template in two separate reactions. Data were normalised to the reference standard by subtracting (in log space) the median observed value if it were other than zero. We used only data points that were reproducible. To this end, we developed a filtering program, PRIM (Kaota et al, 2001). Briefly, this program (i) deletes the results with 'flags' added manually to corrupted spots; (ii) eliminates spots with signal intensities less than the mean $+3 \times$ standard deviation of the background signal intensity in either $\mathrm{Cy} 3$ or $\mathrm{Cy} 5$; and (iii) eliminates spots located outside the least-mean-squares line $\pm 2 \times$ standard deviation. After 
the filtering was finished, we compared the results of the two experiments by calculating a Pearson's correlation coefficient. If the coefficient was equal to or greater than 0.7 , we used the data in subsequent analyses. If not, we repeated the labelling, hybridisation, and scanning up to six times. In this way, we could generate high-quality data for most tissues. Preceeding the clustering, ratio values from duplicate experiments were averaged, log-transformed (base 2), and stored in a table. We applied hierarchical clustering to both axes, using the weighted pair-group method with a centroid average as implemented by the program CLUSTER (Eisen et al, 1998). The results were analysed by using TREEVIEW (Eisen et al, 1998).

\section{Northern blot analysis}

Northern blot was performed as we described previously (Sakakura et al, 1994, 1996). In brief, total cellular RNA was prepared by the guanidine isothiocyanate-phenol-chloroform procedure. Selection of poly $(\mathrm{A})^{+}$RNA was performed by an oligo dT column, then fractionated on $1 \%$ agarose $/ 2.2 \mathrm{M}$ formaldehyde gels. Probes were labelled with ${ }^{32} \mathrm{P}$ by random priming. Each blot was hybridised with probes for each selected gene and $\beta$-actin. We analysed signals with a BAS 2000 image analyser and calculated the degree of overexpression compared to control.

\section{Clinical samples of malignant ascites and peritoneal washes of benign disease}

The study population is consist of 10 patients of gastric cancer with malignant ascites (with positive cytology results) and 10 patients with benign disease including cholecystolithiasis and leiomyoma of the stomach, undergoning surgery at Kyoto Prefectural University of Medicine. Ascites fluid was collected from the Douglas cavity at laparotomy. In the absence of ascites, $50 \mathrm{ml}$ of saline was introduced into the Douglas cavity at the beginning of the operation and aspirated after general stirring. These washes were centrifuged at 2000 r.p.m. for $10 \mathrm{~min}$ to collect intact cells, rinsed with PBS, dissolved in ISOGEN RNA extraction buffer (Nippon Gene, Tokyo), and stored at $-80^{\circ} \mathrm{C}$ until use. All experiments with clinical samples were conducted under institutional guideline from the Ministry of Health and Welfare.

\section{Reverse transcriptase-polymerase chain reaction (RT - PCR)}

cDNA was produced from total RNA by using a Superscript preamplification system (BRL, Bethesda, MD, USA) and following the procedures suggested by the manufacturer. RNA was heated to $65^{\circ} \mathrm{C}$ for $10 \mathrm{~min}$ in $14 \mu \mathrm{l}$ of duethylpyrocarbonate-treated water containing $0.5 \mu \mathrm{g}$ oligo $(\mathrm{dT})$. Synthesis buffer $(10 \times), 2 \mu \mathrm{l}$ $10 \mathrm{~mm}$ dNTP mix, $2 \mu \mathrm{l} 0.1 \mathrm{M}$ DTT, and reverse transcriptase (Superscript RT; $200 \mathrm{U}^{-1}$ ) were added to the sample. The resulting reaction mixture was incubated at $42^{\circ} \mathrm{C}$ for $50 \mathrm{~min}$, and reaction was terminated by incubating the mixture at $95^{\circ} \mathrm{C}$ for $5 \mathrm{~min}$.

The sequences of the three sets of primer used were: Inositol triphospate receptor (IP3R) (sense) 5'-CACGTGAAGTGGGCCATAAC- ${ }^{\prime}$, (antisense) 5' -TCCGTCAGGAACTGGCAGAT-3'; Keratin 7 (sense) 5'-ACCATTAACCAGAGCCTGCT-3', (antisense) 5'-TCATTCAGGGCATCCACCTT-3'; aldehyde dehydrogenase (ALDH) (sense) 5'-ATTGTGTTAGCTGATG CCGACTT-3' (antisense) 5'-CACTGGCCCTGGTGGTAGAATA-3'. PCR was carried out in a reaction mixture $(10 \mu \mathrm{l})$ containing $10 \mathrm{~mm}$ Tris- $\mathrm{HCl}$, $\mathrm{pH} 8.3,50 \mathrm{mM} \mathrm{KCl}, 200 \mu \mathrm{M}$ dNTP, $1.5 \mathrm{mM} \mathrm{MgCl}_{2}, 0.25$ unit of Taq DNA polymerase (Perkin-Elmer Cetus, Branchburg, NJ, USA), $0.2 \mu \mathrm{M}$ primers $\mathrm{A}$ and $\mathrm{B}$, and $1 \mu \mathrm{l}$ of template cDNA. Twenty-five rounds of amplification were performed in a thermo- cycler (MJ Research Inc., Watertown, MA, USA) at $94^{\circ} \mathrm{C}$ for $30 \mathrm{~s}$, $58^{\circ} \mathrm{C}$ for $30 \mathrm{~s}$, and $72^{\circ} \mathrm{C}$ for $30 \mathrm{~s}$, with a final extension step at $72^{\circ} \mathrm{C}$ for $10 \mathrm{~min}$. After PCR, $5 \mu \mathrm{l}$ of the reaction mixture was electrophoresed on a $2 \%$ agarose gel.

\section{RESULTS}

\section{Global gene expression analysis by cDNA microarray of gastric cancer cell lines from malignant ascites}

We performed a global analysis of gene expression of 21168 genes in SNU-1, SNU-5, SNU-16, SNU-620, KATO-III and GT3TKB cells using a high-density cDNA microarray and compared the gene expression profiles of SNU-5, SNU-16, SNU-620, KATO-III and GT3TKB cells with that of SNU-1. To eliminate data with low reliability, genes whose expression was regarded as absent in both cell lines as a result of software analysis were excluded. The results of the analysis by TREEVIEW are shown in Figure 1. Among the 11680 to 15151 genes (known genes and ESTs) expressed, 44 genes showed a differential expression more than double that of SNU-1 and 30 more than half that of other cell lines. To verify these findings, we performed Northern blot to analyse all these genes that showed greater than two-fold difference in terms of cDNA array. When more than two-fold changes in expression level by Northern blot analysis were considered significant, consistency with cDNA microarray analysis were 55\% (41 of 74), whereas no significant change was seen in $27 \%$ ( 20 of 74 ), and discordant results were obtained in $18 \%$ (13 of 74 ). Genes identified both analyses are listed in Tables 2 and 3. Typical data are shown in Figures 2 and 3 .

\section{Expression of selected genes in eight gastric cancer cell lines}

Because the peritoneal dissemination potentials of other gastric cancer cell lines have been reported by several previous studies, we also investigated the expression of the differential gene expression of SNU-1 and other gastric cancer cells by Northern blot analysis. We performed this analysis on another two gastric cancer cell lines in addition to the six cell lines analysed by cDNA microarray, to find any correlation between these genes and the peritoneal dissemination potential of gastric cancer cells (Figures 2 and 3). KATO-III, SNU-5, SNU-16, and SNU-620 are often used as a peritoneal dissemination model in nude mice because of their reportedly high potential for peritoneal dissemination. Although there are no reports on this potential of GT3TKB in nude mice, we confirmed it in an animal experiment, in which NUGC-3 and MKN7 did not generate a peritoneal metastasis even 4 weeks after inoculation. These findings indicated that these cells can be readily classified into three groups: (a) cells with a high potential for peritoneal dissemination (SNU-5, SNU-16, and SNU-620, KATO-III and GT3TKB), (b) main tumour-derived cell line SNU-1 with no potential for peritoneal dissemination and (c) MKN7 and NUGC-3 with low potential or no potential for peritoneal dissemination.

In addition to MKN7 and NUGC3, most genes, CD44 and Keratin family genes are strongly expressed in gastric cancer cells of peritoneal dissemination. Several genes, such as aldehyde dehydrogenase and IP3R, showed a high expression level only in cells with a high potential for such dissemination and a low expression level in all of the cells with a low potential for peritoneal dissemination. These changes in expression may be specific for gastric cancer peritoneal dissemination. Most down-regulated genes, such as p27 are also repressed in all other gastric cancer cell lines, while some of the listed genes, such as IL4 Stat, are more intensively down-regulated in gastric cancer cells of peritoneal dissemination. 


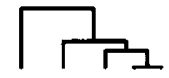

A

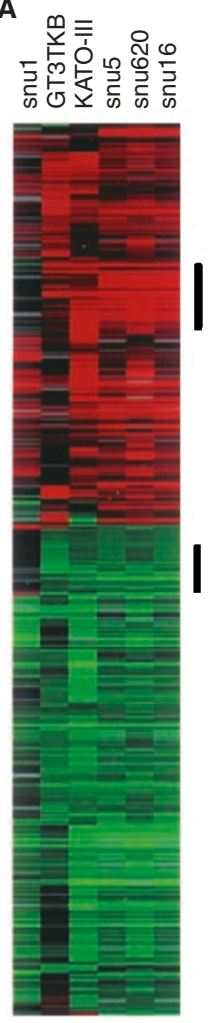

B

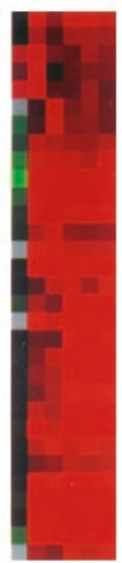

Creative kinace B

asto

EST:

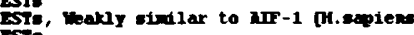

ITI donain only?

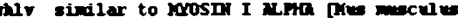

(D) antion for pistome H1(0)

Keratis 14 (enidermol vais bullosa siplex, Domling-Keara, Koebwer

TEB 1-induced anti-apoptotic factor

ESTs, Weakly similar to FER-1 [C.elegars]

FSTs saniene mpan for alutathione transferase M-4

Hewn occludin mpern. complete cds

ESTs. Hiahly similar to OASIS protein MN.meculusi

lectin, galactoside-binding

wracil-Dur wlvcosvlase 2 . Dowa decarboxylate (aromatic L-and so acid decarboxylase)

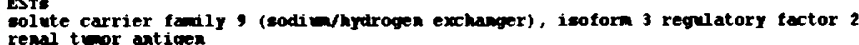
renal teror antigen Meratin IoG Fc recentor warn marh. complete cole meuroblationa candidate region, suppression of tumprigenicity 1

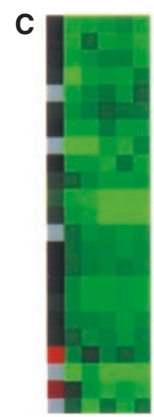

ESTs

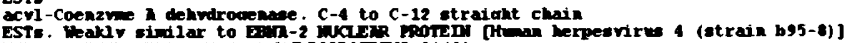

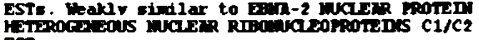

ESTs
exoortin. tren (auclear exwort receptor tor trene)

H2M kistove fonily, wher $\mathrm{L}$

EST:

ESTs, Weakly sinilar to KrMne424 [H.eopiess]

Ests neobindin ?

ESTs

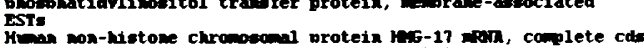

arvl introcarbon receptor-interactima protein

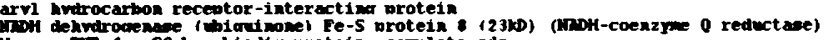

Hand wion tor GC box bistig protein, complete cds

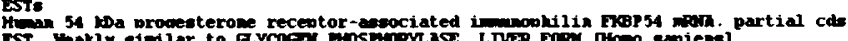

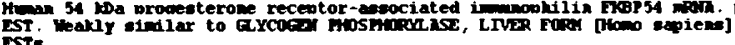

Figure I High-density cDNA microarray analysis. Validation in expression of selected genes from 2168 clones in six gastric cancer cell lines. Data are represented in a matrix format: each row represents a single gene, and each column an experimental sample. In each sample, the ratio of the number of transcripts of each gene to the medium abundance of the gene's transcript among all the cell lines is represented by the colour of the corresponding cell in the matrix. Green square,transcript level below the median; black squares, transcript levels equal to the medium; red squares, transcript levels greater than the median. Colour saturation reflects the magnitude of the ratio relative to the median for each set of samples. (A) Cluster analysis of selected genes of six gastric cancer cell lines using the RIKEN cDNA microarray. Bars to the right identify the location of the inserts displayed in panels $\mathbf{B}$ and $\mathbf{C}$. (B) Up-regulated genes in gastric cancer cells from malignant ascites. (C) Down-regulated genes in gastric cancer cells from malignant ascites

\section{Experimental model in nude mouse}

Intraperitoneal inoculation of KATO-III or GT3TKB cells resulted in nodules in the peritoneal cavity, while the other cell lines, SNU5, SNU-16, and SNU-620, formed nodules and malignant ascites. In contrast, no disseminated foci could be detected after intraperitoneal inoculation of either MKN7 or NUGC3. Potency of intraperitoneal transplantation in these cancer cells is shown in Table 1.

\section{RT - PCR}

A specific PCR fragment was successfully amplified by RT - PCR for each set of primers with the expected size. Direct sequencing confirmed that these bands could be identified with each of the amplified sequences. The specific band was detected in all ten samples of malignant ascites tested with each of three different target genes. In contrast, none of the 10 patients with benign disease was positive, although shallow bands were detected in some of them. Typical data are shown in Figure 4. These results suggest that genes selected by DNA microarray were overexpressed in the gastric cancer cell lines established from the metastases to the peritoneal cavity as well as in the clinical samples of malignant ascites.

\section{DISCUSSION}

The introduction of novel improved array technologies has resulted in new possibilities for studying the molecular mechanisms of cancer metastasis. In our study, the relative mRNA levels of genes expressed in the cell lines examined were identified by using cDNA microarrays. The array analysis suggested that the genes shown in Table 2 were up-regulated and those in Table 3 were significantly down-regulated. With regard to peritoneal dissemination, malignant characteristics of cancer cells such as reduced intercellular adhesion, increased cell-to-matrix adhesion, and resistance to apoptosis are considered to be important features. Several of the 41 genes that showed different expression levels in SNU-1 and other cell lines different from those of malignant ascites have been previously reported to be related to these features. The possible involvement of other genes listed in Tables 2 and 3 to peritoneal dissemination of gastric cancers has not yet been reported. Other expression sequence tags (ESTs) can be expected to be involved in peritoneal dissemination, but the precise function of each gene remains unclear, so that further study would be necessary to clarify it.

Previous reports have shown gene expression profiles in schirrous gastric cancer cell lines as well as xenografts of gastric cancers in nude mice (El-Rifai et al, 2001; Hippo et al, 2001). As we screened more than 21000 genes, we could select more novel 
Table 2 Up-regulated genes in gastric cancer cells from malignant ascites in comparison to those from primary lesion

\begin{tabular}{|c|c|c|c|c|c|}
\hline No. & $\begin{array}{l}\text { Gene bank } \\
\text { (accession) }\end{array}$ & $\begin{array}{c}\text { Northern } \\
\text { blot (mean) }\end{array}$ & $\begin{array}{c}\text { Gene chip } \\
\text { (mean) }\end{array}$ & Gene name & Function \\
\hline I & AA486275 & 3.2 & 3.63 & Leukocyte elastase inhibitor & Apoptosis \\
\hline 2 & AA446222 & 5.7 & 4.29 & TGF $\beta$-induced antiapoptotic factor & Apoptosis \\
\hline 3 & AA424695 & 2.3 & 2.14 & Integrin alpha3 & Cell adhesion \\
\hline 4 & AA44405I & 3.3 & 2.58 & SIO0 AIO (ligand of Annexin II) & Cell adhesion \\
\hline 5 & AA630328 & 4.3 & 6.02 & Galectin 3 (lectin) & Cell adhesion \\
\hline 6 & H9447I & 2.1 & 7.84 & Occludin & Cell adhesion \\
\hline 7 & AA282906 & 6.5 & 9.58 & CD44 & Cell adhesion \\
\hline 8 & R33456 & 7.3 & 15.89 & Desmoplakin (DPI, DPII) & Cell adhesion \\
\hline 9 & $\mathrm{H} 4405$ I & 6.5 & 10.48 & Keratin 14 & Cell adhesion, invasion \\
\hline 10 & AA598517 & 15.9 & 13.64 & Keratin 8 & Cell adhesion, invasion \\
\hline II & AA489569 & 10.3 & 25.63 & Keratin 7 & Cell adhesion, invasion \\
\hline 12 & R93124 & 15.3 & 24.08 & Aldo-keto reductase family I & Drug metabolism \\
\hline 13 & AA664I0I & 14.7 & 33.13 & Aldehyde dehydrogenase & Drug metabolism \\
\hline 14 & N77779 & 2.5 & 5.78 & Renal tumour antigen RAGEI & Immune response \\
\hline 15 & AA424824 & 3.1 & 4.29 & Destrin (actin depolymerising factor) & Interaction with extracellular matrix \\
\hline 16 & AA625890 & 3.8 & 7.46 & Myosin 6 & Intracellular organelle transport \\
\hline 17 & AA425938 & 3.1 & 2.3 & Cystein protease (legumain) & Invasion \\
\hline 18 & $\mathrm{H} 22826$ & 4.1 & 5.66 & LMO 7 & Signalling \\
\hline 19 & AA49669I & 5.1 & 6.19 & Dystroglycan | & Signalling \\
\hline 20 & AA455369 & 4.2 & 2.55 & Sodium/hydrogen exchanger, isoform I & Signalling \\
\hline 21 & AA281735 & 11.4 & 15.56 & Inositol triphosphate receptor & Signalling \\
\hline 22 & AA4I 2053 & 7.8 & 16.34 & CD9 & Signalling \\
\hline 23 & AA25319 & 3.1 & 2.27 & Caveolin-3 & Signalling (modification) \\
\hline 24 & AA702640 & 7.6 & 11.08 & Dopa decarboxylase & Signalling or progression \\
\hline
\end{tabular}

GenBank accession number, fold change verified by high-density oligonucleotide array and Northern blot, and one representative function of the genes as previously reported are shown. Only the genes that showed more than two-fold change in expression by cDNA array and greater than two-fold by Northern blot are listed, and genes are sorted by Northern blot data

Table 3 Down-regulated genes in gastric cancer cells from malignant ascites in comparison to those from primary lesion

\begin{tabular}{|c|c|c|c|c|c|}
\hline No. & $\begin{array}{l}\text { Gene bank } \\
\text { (accession) }\end{array}$ & $\begin{array}{l}\text { Northern } \\
\text { blot (mean) }\end{array}$ & $\begin{array}{c}\text { Gene chip } \\
\text { (mean) }\end{array}$ & Gene name & Function \\
\hline I & AA453105 & 0.5 & 0.29 & H2A histone family member $L$ & Apoptosis \\
\hline 2 & AA025275 & 0.3 & 0.35 & Death associated protein & Apoptosis \\
\hline 3 & AA485668 & 0.3 & 0.37 & Integrin $\beta 4$ & Cell adhesion \\
\hline 4 & H37989 & 0.2 & 0.52 & Tubulin beta-I chain & Cell structure \\
\hline 5 & T97593 & 0.2 & 0.37 & Heterogenous nuclear ribonucleoprotein & Cell structure \\
\hline 6 & T64I50 & 0.4 & 0.46 & RAD5I homologue C & Chromosome stability \\
\hline 7 & H79047 & 0.3 & 0.16 & IGFBP2 & Growth and metabolism \\
\hline 8 & N75745 & 0.2 & 0.09 & IL2 receptor gamma & Immune response \\
\hline 9 & AA476285 & 0.2 & 0.37 & CD4 & Immune response \\
\hline 10 & T72202 & 0.3 & 0.46 & IL4 stat & Immune response \\
\hline 11 & AA236617 & 0.4 & 0.37 & PAK-interacting exchange factor alpha & Signalling \\
\hline 12 & AA630082 & 0.1 & 0.41 & p27kip & Signalling \\
\hline 13 & AA629692 & 0.3 & 0.46 & Chaperonin containing TCPI & Signalling \\
\hline 14 & W46769 & 0.2 & 0.61 & Histone deacetylase 3 & Signalling \\
\hline 15 & AA4852I4 & 0.2 & 0.22 & Nucleobinding 2 & Signalling (apoptosis) \\
\hline 16 & W86653 & 0.1 & 0.11 & FKBP54 & Signalling \\
\hline 17 & $\mathrm{H} 96140$ & 0.2 & 0.43 & Acyl-Coenzyme A dehydrogenase & Signalling \\
\hline
\end{tabular}

GenBank accession number, fold change verified by high-density oligonucleotide array and Northern blot, and one representative function of the genes as previously reported are shown. Only the genes that showed expression change greater than two-fold by cDNA array and greater than two-fold by Northern blot are listed, and genes are sorted according to Northern blot data.

genes that have not reported previously in gastric cancers. Selected genes of Tables 2 and 3 were singled out according to their function and are discussed in relation to previous reports.

\section{Genes related to signalling (growth and metabolism)}

Although growth factors, their ligands and down-stream molecules are frequenly overexpressed in cancer cells, to the best of our knowledge, several genes related to signalling as listed in Table 2, have not been reported previously. The extracellular domain of CD9 binds the epidermal growth factor (EGF) and enhances the function of EGF signalling (Nakamura et al, 2000; Hashida et al, 2002). Dopa decarboxylase (DDC) is responsible for the synthesis of the key neurotransmitters dopamine and serotonin, and is frequently expressed in neuroblastoma and small cell carcinoma of the lung (North and Du, 1998; Gilbert et al, 1999). Sodium/ hydrogen exchanger isoform 1, is activated more in malignant gliomas than nontransformed astrocytes, and malignant gliomas display altered $\mathrm{pH}$ regulation (Lagana et al, 2000; McLean et al, 2000). LMO7 in gastric cancer has not been dealt with in any reports, but another isoform, LMO4 (a transcriptional regulator) inhibits differentiation of mammary epithelial cells in vitro and is 


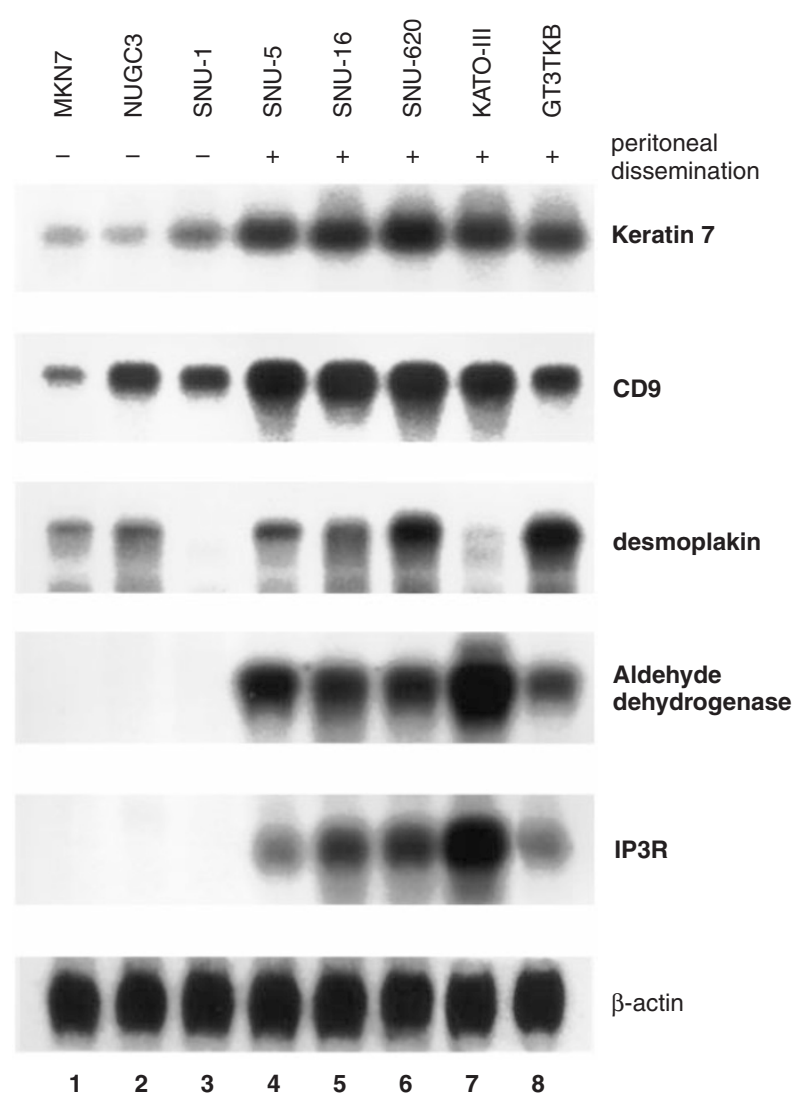

Figure 2 Northern blot analysis of differently expressed genes in eight gastric cancer cells. Up-regulated genes in gastric cancer cells from malignant ascites in comparison to primary lesion

overexpressed in breast cancers (Putilina et al, 1998; Kurihara et al, 2002). Inositol 1, 4, 5-triphospate receptor type $3(\operatorname{IP}(3) \mathrm{R} 3)$ is frequently expressed in secretion cells and known to be related to the IP3 signalling pathway, $\mathrm{Ca}^{2+}$ influx, enzyme secretion and cell motility (Broad et al, 2001; Lee and Laychock, 2001), but its role in peritoneal dissemination is still unclear. Aldoketoreductase and aldehyde dehydrogenase (ALDH) belong to a family of several isoenzymes important in cell defence against both exogenous and endogenous aldehydes (Deichmann et al, 1999; Canuto et al, 2001). Compared with expression of ALDH in normal hepatocytes, several changes were observed in rat hepatoma cells (Canuto et al, 2001). PAK-interacting exchange factor (PIX) has been reported to mediate the recruitment of PAK into focal adhesions and thus to create a feedback loop that stimulates PAK and other molecules (Wang et al, 2001). Down-regulation of histon deacetylase 3 has also been detected, as has inactivation of many tumour suppressor genes and cell cycle regulators by methylation (Ozawa et al, 2001). Histon deacetylase 3 was down-regulated in tumour cell lines and may be related to the suppression of tumour suppressor genes or cell cycle regulators. Prenatal diagnosis of multiple acyl-CoA dehydrogenase deficiency associated with elevated alpha-fetoprotein and cystic renal change has been established (Chisholm et al, 2001). But the precise roles of these genes in metastasis have not been identified, however, so that further study is necessary.

\section{Genes related to cell adhesion and motility}

Several genes related to cell adhesion, invasion, adhesion to extracellular matrix, and growth factors were abundantly over-expressed in our cell lines derived from malignant ascites. CD44 (Hsieh et al,

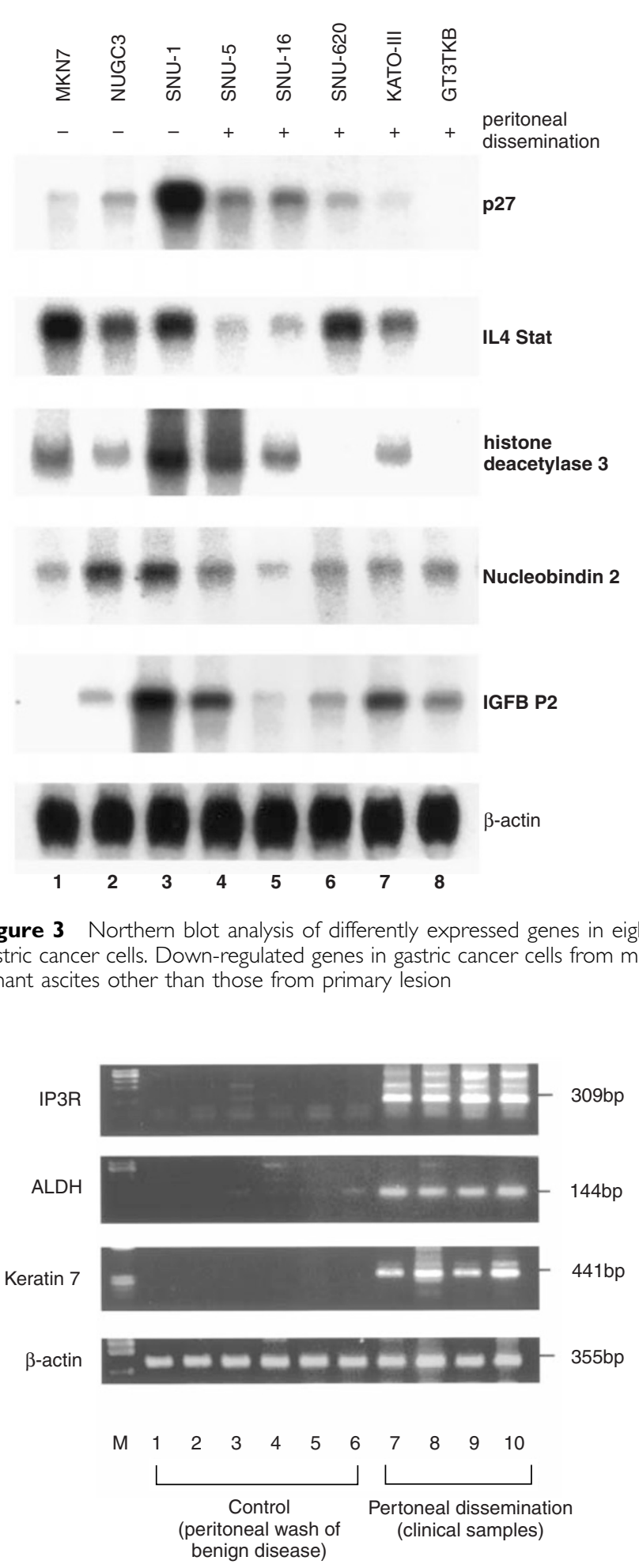

Figure 4 Expression of selected genes in clinical samples of peritoneal dissemination. Representative RT-PCR results of six peritoneal washes from patients with benign disease (cytology negative) and from four gastric cancer patients with malignant ascites (cytology positive). Arrows indicate the specific bands of each gene

1999), keratins 7 and 8 (Martens et al, 1999) are overexpressed in several different kinds of cancers. Galectin 4 has been found to be overexpressed in breast cancers and schirrous gastric cancer cell 
lines (Hippo et al, 2001; Moon et al, 2001). The involvement of integrin alpha 3 and beta 4 have also been reported in cancer metastasis (Ishii et al, 2000; Chu et al, 2001; Galbiati et al, 2001). However, to our knowledge, no other reports related to galectin 3, S100A10, desmoplakin, occludin, keratins 8, 14, myosin VI, tubulin beta 4 and calveolin-3 in gastric cancer have been published. Calcium binding protein S100A10 is reported to be overexpressed in renal cell carcinoma (Teratani et al, 2002) and may exert its effect on metastasis formation by stimulating the motility and invasive properties of gastric cancer cells. Calveolin3 , a muscle-specific caveolin-related protein is the principal structural protein of caveolar membrane domains, which appear to be important for signal transduction in skeletal muscle and in the heart (Razani et al, 2000). Keratin family genes, such as Keratins 7,8 , and 14, have different specificity, and some of them are reportedly expressed in cancer cells to facilitate the latter's attachment to the peritoneum, and to promote liver metastasis of some cancers. They are also known to be involved in cell migration, cell invasiveness, plasminogen activity and drug and radiation resistance (Martens et al, 1999). Myosin VI is expressed in a variety of cell types and is thought to play a role in membrane trafficking and and endocytosis (Rock et al, 2001; Yoshimura et al, 2001). Tubulin beta 4 is downregulated in hepatoma cells than in normal liver cells (Yu et al, 2000). Although desmoplakin and dystroglycan are commonly down-regulated in clinical cancer specimens, they were overexpressed in our study (Davies et al, 1999; Henry et al, 2001). Their expression may be up-regulated again when cancer cells are disseminated on the methelium. Whether these genes are actually involved in peritoneal dissemination is a matter to be further investigated.

\section{Genes related to immunity}

Down-regulation of CD4, IL2 receptor gamma and IL4-Stat genes is extremely intriguing. CD4 and CD8 are co-receptor molecules on lymphocytes and generally perform a helper or cytotoxic function. Although loss of CD4 expression on lymphocytes is known to correlate with the cytotoxic function, the role of CD4 expression in cancer cells remains unclear. Down-regulation of IL4 Stat, which is an important regulator of signalling from IL13 through the IL4R-STAT6 pathway, is necessary for downregulation of tumour immuno-surveillance from NKT cells. It is reported that both IL4 and IL13 share signalling events in human colon carcinoma cell lines (HT29 and WiDr), and that both IL13 and IL4 induce phosphorylation of IL4 STAT (STAT6) (Murata et al, 1996; Terabe et al, 2000). The leukocyte elastase inhibitor is one of the possible target genes of PTEN (Hong et al, 2000). Up-regulation of leukocyte elastase inhibitor is thought to protect cancer cells from damage by immune cells, so that weakness of the IL13-IL4 Stat signalling pathway would allow cancer cells to escape from the immune response of the host. FKBP54 is known as a novel immunophilin (Milad et al, 1995; Zhu et al, 2001).

\section{Genes related to apoptosis and cell cycle}

Histone $\mathrm{H} 2 \mathrm{~A}$ is related to chromatin condensation in TGF $\beta 1$ induced apoptosis (Marushige and Marushige, 1995), while heterogenous nuclear ribonucleoprotein $\mathrm{A} 1$ seems to be related to the potensity to develop metastases (Ghigna et al, 1998). Using COXs as bait in the yeast two-hybrid system, we identified autoimmunity and apoptosis-associated nucleobindin (Nuc) as a protein that specifically interacts with both isoenzymes (Ballif et al, 1996). It is known a reduced expression of CDK inhibitor p27 produces a malignant phenotype of cancer cells (Porter et al, 1997; Xiangming et al, 2000). Post-transcriptional regulation of p27 has been reported. Although p27 down-regulation would not be specific to peritoneal dissemination, p27 may be involved in cancer progression such as peritoneal dissemination.

Gene expression changes in adhesion molecules, signalling molecules, growth factor receptors, drug metabolism and immune response are likely to contribute to the complexicity of gastric cancer peritoneal dissemination. Overexpression or down-regulation of these genes in highly metastatic cells, as we have shown in this study, is in good concordance with the findings of previous reports (El-Rifai et al, 2001; Hippo et al, 2001) and indicates that gene expression changes in these cells accurately reflects some metastatic characteristics. For example, CD44 and galectin 3 (Hsieh et al, 1999; Moon et al, 2001), genes relevant for cancer metastasis, were up-regulated in peritoneal metastasis. Integrin $\beta_{4}$ has recently been reported to be a suppressor of peritoneal dissemination of gastric cancer (Ishii et al, 2000). But our results and those of previous reports are somewhat different, suggesting that histological differences in samples used for these studies is responsible for the difference in gene expression.

Although the initial discrepancy between the data obtained in this study with high-density cDNA microarray and those obtained with Northern blot was not negligible, the final data presented here were verified by two different methods and are considered be highly reliable. cDNA microarray analysis greatly facilitated clarification of a major aspect of gastric cancer metastasis by identifying the global changes in gene expression. In this study, however, these genes showed different expression patterns among the eight gastric cancer cell lines, and some genes showed apparent correlation, while others did not, with their peritoneal dissemination potential. These results clearly show that a complex in vivo phenomenon such as peritoneal dissemination can not be explained by altered expression of a single gene. Thus, the relevance of exploring the global gene expression profile by using a comprehensive procedure is obvious.

In conclusion, a combination of gene expression changes in these genes leads to peritoneal dissemination of gastric cancers. This implies that autocrine production of these growth factors and their receptors by cancer cells may strongly promote invasion and metastasis. Whether these genes are actually involved in peritoneal dissemination, however, is a matter to be further investigated. A comparison between gene expression profiles of highly metastatic cell lines may identify coordinate genes that function as biological markers of peritoneal dissemination. Most of the up-regulated genes listed in Table 2 are overexpressed in most gastric cancer cell lines, but a few genes are likely to be strongly expressed in gastric cancer cells of peritoneal dissemination. Our preliminary experiments indicate that at least several of the genes listed in Table 2 were also frequently overexpressed in clinical samples of peritoneal dissemination. Identification of such genes could then lead to new therapeutic modalities as well as therapeutic targets.

\section{ACKNOWLEDGEMENTS}

This work was supported by a grant-in-aid for Cancer Research from the Ministry of Health and Welfare and from the Ministry of Education, Science and Culture, and by grants from the Uehara Memorial Foundation and Sagawa Memorial Foundation, Japan. 


\section{REFERENCES}

Ballif BA, Mincek NV, Barratt JT, Wilson ML, Simmons DL (1996) Interaction of cyclooxygenases with an apoptosis- and autoimmunity-associated protein. Proc Natl Acad Sci USA, 93: 5544-5549

Broad LM, Braun FJ, Lievremont JP, Bird GS, Kurosaki T, Putney Jr JW (2001) Role of the phospholipase C-inositol 1,4,5-trisphosphate pathway in calcium release-activated calcium current and capacitative calcium entry. J Biol Chem 276: 15945-15952

Canuto RA, Ferro M, Salvo RA, Bassi AM, Trombetta A, Maggiora M, Martinasso G, Lindahl R, Muzio G (2001) Increase in class 2 aldehyde dehydrogenase expression by arachidonic acid in rat hepatoma cells. Biochem J, 357: 811-818

Chisholm CA, Vavelidis F, Lovell MA, Sweetman L, Roe CR, Roe DS, Frerman FE, Wilson WG (2001) Prenatal diagnosis of multiple acyl-CoA dehydrogenase deficiency: association with elevated alpha-fetoprotein and cystic renal changes. Prenat Diagn, 21: 856-859

Chu PG, Lyda MH, Weiss LM (2001) Cytokeratin 14 expression in epithelial neoplasms: a survey of 435 cases with emphasis on its value in differentiating squamous cell carcinomas from other epithelial tumours. Histopathology 39: 9-16

Davies EL, Gee JM, Cochrane RA, Jiang WG, Sharma AK, Nicholson RI, Mansel RE (1999) The immunohistochemical expression of desmoplakin and its role in the progression and metastasis of breast cancer. Eur J Cancer 35: $902-907$

Deichmann M, Benner A, Bock M, Jackel A, Uhl K, Waldmann V, Naher H (1999) S100-Beta, melanoma-inhibiting activity, and lactate dehydrogenase discriminate progressive from nonprogressive American Joint Committee on Cancer stage IV melanoma. J Clin Oncol 17: 1891-1896

Eisen MB, Spellman PT, Brown PO, Botstein D (1998) Cluster analysis and display of genome-wide expression patterns. Proc Natl Acad Sci USA, 95: $14863-14868$

El-Rifai W, Frierson Jr HF, Harper JC, Powell SM, Knuutila S (2001) Expression profiling of gastric adenocarcinoma using cDNA array. Int $J$ Cancer 92: $832-838$

Galbiati F, Razani B, Lisanti MP (2001) Caveolae and caveolin-3 in muscular dystrophy. Trends Mol Med 7: 435-441

Ghigna C, Moroni M, Porta C, Riva S, Biamonti G (1998) Altered expression of heterogenous nuclear ribonucleoproteins and SR factors in human colon adenocarcinomas. Cancer Res 58: 5818-5824

Gilbert J, Haber M, Bordow SB, Marshall GM, Norris MD (1999) Use of tumour-specific gene expression for the differential diagnosis of neuroblastoma from other pediatric small round-cell malignancies. Am J Pathol, 155: $17-21$

Hashida H, Takabayashi A, Tokuhara T, Taki T, Kondo K, Kohno N, Yamaoka Y, Miyake M (2002) Integrin alpha3 expression as a prognostic factor in colon cancer: association with MRP-1/CD9 and KAI1/CD82. Int J Cancer, 97: $518-525$

Henry MD, Cohen MB, Campbell KP (2001) Reduced expression of dystroglycan in breast and prostate cancer. Hum Pathol 32: $791-795$

Hippo Y, Yashiro M, Ishii M, Taniguchi H, Tsutsumi S, Hirakawa K, Kodama T, Aburatani H (2001) Differential gene expression profiles of scirrhous gastric cancer cells with high metastatic potential to peritoneum or lymph nodes. Cancer Res 61: 889-895

Hojo H (1977) Establishment of cultured cell lines of human stomach cancer origin and their morphological characteristics. Niigata Igakkai Zasshi 91: $737-763$ (in Japanese)

Hong TM, Yang PC, Peck K, Chen JJ, Yang SC, Chen YC, Wu CW (2000) Profiling the downstream genes of tumour suppressor PTEN in lung cancer cells by complementary DNA microarray. Am J Respir Cell Mol Biol 23: $355-363$

Hsieh HF, Yu JC, Ho LI, Chiu SC, Harn HJ (1999) Molecular studies into the role of CD44 variants in metastasis in gastric cancer. Mol Pathol 52: 25-28

Ishii Y, Ochiai A, Yamada T, Akimoto S, Yanagihara K, Kitajima M, Hirohashi S (2000) Integrin alpha6beta4 as a suppressor and a predictive marker for peritoneal dissemination in human gastric cancer. Gastroenterology 18: $497-506$

Kaota K, Miki R, Bono H, Shimizu K, Okazaki Y, Hayashizaki Y (2001) Preprocessing implementation for microarray (PRIM): an efficient method for processing cDNA microarray data. Physiol Genomics 4: 183-188

Katoh M, Hattori Y, Sasaki H, Tanaka M, Sugano K, Yazaki Y, Sugimura T, Terada M (1992) K-sam gene encodes secreted as well as transmembrane receptor tyrosine kinase. Proc Natl Acad Sci USA 89: 2960-2964
Kurihara LJ, Semenova E, Miller W, Ingram RS, Guan XJ, Tilghman SM (2002) Candidate genes required for embryonic development: a comparative analysis of distal mouse chromosome 14 and human chromosome 13q22. Genomics 79: $154-161$

Lagana A, Vadnais J, Le PU, Nguyen TN, Laprade R, Nabi IR, Noel J (2000) Regulation of the formation of tumour cell pseudopodia by the $\mathrm{Na}(+) /$ $\mathrm{H}(+)$ exchanger NHE1. J Cell Sci 113: (Pt 20): 3649-3662

Lee B, Laychock SG (2001) Inositol 1,4,5-trisphosphate receptor isoform expression in mouse pancreatic islets: effects of carbachol. Biochem Pharmacol 61: 327-336

Martens J, Baars J, Smedts F, Holterheus M, Kok MJ, Vooijs P, Ramaekers F (1999) Can keratin 8 and 17 immunohistochemistry be of diagnostic value in cervical cytology? A feasibility study. Cancer 87: 87-92

Marushige Y, Marushige K (1995) Disappearance of ubiquitinated histone H2A during chromatin condensation in TGF beta 1-induced apoptosis. Anticancer Res 15: 267-272

McLean LA, Roscoe J, Jorgensen NK, Gorin FA, Cala PM (2000) Malignant gliomas display altered $\mathrm{pH}$ regulation by NHE1 compared with nontransformed astrocytes. Am J Physiol Cell Physiol 278: C676-C688

Miki R, Kadota K, Bono H, Mizuno Y, Tomaru Y, Carninci P, Itoh M, Shibata K, Kawai J, Konno H, Watanabe S, Sato K, Tokusumi Y, Kikuchi N, Ishii Y, Hamaguchi Y, Nishizuka I, Goto H, Nitanda H, Satomi S, Yoshiki A, Kusakabe M, DeRisi JL, Eisen MB, Iyer VR, Brown PO, Muramatsu M, Shimada H, Okazaki Y, Hayashizaki Y (2001) Delineating developmental and metabolic pathways in vivo by expression profiling using the RIKEN set of 18,816 full-length enriched mouse cDNA arrays. Proc Natl Acad Sci USA 98: 2199-2204

Milad M, Sullivan W, Diehl E, Altmann M, Nordeen S, Edwards DP, Toft DO (1995) Interaction of the progesterone receptor with binding proteins for FK506 and cyclosporin A. Mol Endocrinol 9: 838-847

Moon BK, Lee YJ, Battle P, Jessup JM, Raz A, Kim HR (2001) Galectin-3 protects human breast carcinoma cells against nitric oxide-induced apoptosis: implication of galectin-3 function during metastasis. Am J Pathol 159: $1055-1060$

Murata T, Noguchi PD, Puri RK (1996) IL-13 induces phosphorylation and activation of JAK2 Janus kinase in human colon carcinoma cell lines: similarities between IL-4 and IL-13 signalling. J Immunol 156: 2972 - 2978

Nakamura K, Mitamura T, Takahashi T, Kobayashi T, Mekada E (2000) Importance of the major extracellular domain of CD9 and the epidermal growth factor (EGF)-like domain of heparin-binding EGF-like growth factor for up-regulation of binding and activity. I Biol Chem 275: $18284-18290$

North WG, Du J (1998) Key peptide processing enzymes are expressed by a variant form of small-cell carcinoma of the lung. Peptides 19: 1743-1747

Ozawa Y, Towatari M, Tsuzuki S, Hayakawa F, Maeda T, Miyata Y, Tanimoto M, Saito H (2001) Histone deacetylase 3 associates with and represses the transcription factor GATA-2. Blood 98: 2116-2123

Park JG, Frucht H, LaRocca RV, Bliss Jr DP, Kurita Y, Chen TR, Henslee JG, Trepel JB, Jensen RT, Johnson BE et al (1990) Characteristics of cell lines established from human gastric carcinoma. Cancer Res 50: 2773-2780

Park JG, Yang HK, Kim WH, Chung JK, Kang MS, Lee JH, Oh JH, Park HS, Yeo KS, Kang SH, Song SY, Kang YK, Bang YJ, Kim YH, Kim JP (1997) Establishment and characterization of human gastric carcinoma cell lines. Int J Cancer 70: $443-449$

Park K, Kim SJ, Bang YJ, Park JG, Kim NK, Roberts AB, Sporn MB (1994) Genetic changes in the transforming growth factor beta (TGF-beta) type II receptor gene in human gastric cancer cells: correlation with sensitivity to growth inhibition by TGF-beta. Proc Natl Acad Sci USA 91: $8772-8776$

Parkin DM, Pisani P, Ferlay J (1999) Estimates of the worldwide incidence of 25 major cancers in 1990. Int J Cancer 80: 827-841

Porter PL, Malone KE, Heagerty PJ, Alexander GM, Gatti LA, Firpo EJ, Daling JR, Roberts JM (1997) Expression of cell-cycle regulators p27Kip1 and cyclin E, alone and in combination, correlate with survival in young breast cancer patients. Nat Med 3: $222-225$

Putilina T, Jaworski C, Gentleman S, McDonald B, Kadiri M, Wong P (1998) Analysis of a human cDNA containing a tissue-specific alternatively spliced LIM domain. Biochem Biophys Res Commun 252: 433-439

Razani B, Schlegel A, Lisanti MP (2000) Caveolin proteins in signalling, oncogenic transformation and muscular dystrophy. J Cell Sci 113: 2103-2109 
Rock RS, Rice SE, Wells AL, Purcell TJ, Spudich JA, Sweeney HL (2001) Myosin VI is a processive motpr with a large step size. Proc Natl Acad Sci USA 98: $13655-13659$

Ross DT, Scherf U, Eisen MB, Perou CM, Rees C, Spellman P, Iyer V, Jeffrey SS, Van de Rijn M, Waltham M, Pergamenschikov A, Lee JC, Lashkari D, Shalon D, Myers TG, Weinstein JN, Botstein D, Brown PO (2000) Systematic variation in gene expression patterns in human cancer cell lines. Nat Genet 24: $227-235$

Sakakura C, Ymaguchi-Iwai Y, Satake M, Bae SC, Takahashi A, Ogawa E, Hagiwara A, Takahashi T, Murakami A, Makino K, NakagawaA T, Kamada N, Ito Y (1994) Growth inhibition and induction of differentiation of $\mathrm{t}(8 ; 21)$ acute myeloid leukemia cells by the DNA-binding domain of PEBP2 and the AML1/MTG8(ETO)-specific antisense oligonucleotide. Proc Natl Acad Sci USA 91: 11723-11727

Sakakura C, Sweeney EA, Shirahama T, Igarashi Y, Hakomori S, Nakatani H, Tsujimoto H, Imanishi T, OhgakiH M, Ohyama T, Yamazaki J, Hagiwara A, Yamaguchi T, Sawai K, Takahashi T (1996) Overexpression of bax sensitizes human breast cancer MCF-7 cells to radiation-induced apoptosis. Int J Cancer 67: 101-105

Scherf U, Ross DT, Waltham M, Smith LH, Lee JK, Tanabe L, Kohn KW, Reinhold WC, Myers TG, Andrews DT, Scudiero DA, Eisen MB, Sausville EA, Pommier Y, Botstein D, Brown PO, Weinstein JN (2000) A gene expression database for the molecular pharmacology of cancer. Nat Genet 24: $236-244$

Sekiguchi M, Sakakibara K, Fujii G (1978) Establishment of cultured cell lines derived from human gastric carcinoma. Jap J Exp Med 48: 61-68

Shimada K, Ajani JA (1999) Adjuvant therapy for gastric carcinoma patients in the past 15 years: a review of western and oriental trials. Cancer 1: $1657-1668$

Tahara E (2000) Molecular aspects of invasion and metastasis of stomach cancer. Verh Dtsch Ges Patol 84: $43-49$

Tahara E, Semba S, Tahara H (1996) Molecular biological observations in gastric cancer. Semin Oncol 23: $307-315$

Tamura G, Sakata K, Nishizuka S, Maesawa C, Suzuki Y, Iwaya T, Terashima M, Saito K, Satodate R (1996) Inactivation of the E-cadherin gene in primary gastric carcinomas and gastric carcinoma cell lines. Jpn J Cancer Res 87: $1153-1159$
Terabe M, Matsui S, Noben-Trauth N, Chen H, Watson C, Donaldson DD, Carbone DP, Paul WE, Berzofsky JA (2000) NKT cell-mediated repression of tumour immunosurveillance by IL-13 and the IL-4R-STAT6 pathway. Nat Immunol 1: 515-520

Teratani T, Watanabe T, Kuwahara F, Kumagai H, Kobayashi S, Aoki U, Ishikawa A, Arai K, Nozawa R (2002) Induced transcriptional expression of calcium-binding protein S100A1 and S100A10 genes human renal carcinoma. Cancer Lett 175: $71-77$

Wang YJ, Oba SM, Yoshii S, Song JP, Wang Y, Kanamori M, Ota S, Tanaka M, Sugimura H (2001) Genomic structure of human alpha-pix, and variable deletions in a poly ( $\mathrm{T})$ tract in gastric cancer tissue. . Cancer Lett 164: $69-75$

Xiangming C, Natsugoe S, Takao S, Hokita S, Tanabe G, Baba M, Kuroshima K, Aikou T (2000) The cooperative role of p27 with cyclin E in the prognosis of advanced gastric carcinoma. Cancer 89: 1214-1219

Yamazaki H, Oshima A, Murakami R, Endoh S, Ubukata T (1989) A longterm follow-up study of patients with gastric cancer detected by mass screening. Cancer 63: 613-617

Yawata A, Adachi M, Okuda H, Naishiro Y, Takamura T, Hareyama M, Takayama S, Reed JC, Imai K (1998) Prolonged cell survival enhances peritoneal dissemination of gastric cancer cells. Oncogene 16: 2681-2686

Yoshimura M, Homma K, Saito J, Inoue A, Ikebe R, Ikebe M (2001) Dual regultion of mammalian myosin VI motor function. J Biol Chem 276: $396-397$

Yu LR, Zeng R, Shao XX, Wang N, Xu YH, Xia QC (2000) Identification of differentially expressed proteins between human hepatoma and normal liver cell lines by two-dimensional electrophoresis and liquid chromatography-ion trap mass spectrometry. Electrophoresis 21: 3058-3068

Zhu W, Zhang JS, Young CY (2001) Silymarin inhibits function of the androgen receptor by reducing nuclear localization of the receptor in the human prostate cancer cell line LNCaP. Carcinogenesis 22: 1399-1403 